\title{
Variability of the date of monsoon onset over Kerala (India) of the period $1870-2014$ and its relation to sea surface temperature
}

\author{
P N Preenu ${ }^{1}$, P V Joseph ${ }^{2}$ and P K Dineshkumar ${ }^{1, *}$ \\ ${ }^{1}$ CSIR-National Institute of Oceanography, Regional Centre, Kochi, Kerala 682 018, India. \\ ${ }^{2}$ Nansen Environmental Research Centre India, 6A Oxford Business Centre, Kochi, Kerala 682 016, India. \\ *Corresponding author. e-mail: dineshku@nio.org
}

MS received 11 February 2016; revised 11 January 2017; accepted 27 February 2017; published online 25 July 2017

Monsoon onset over Kerala (India) which occurs every year is a major climatic phenomenon that involves large scale changes in wind, rainfall and sea surface temperature (SST). Over the last 150 years, the date of monsoon onset over Kerala (DMOK) has varied widely, the earliest being 11 May, 1918 and the most delayed being 18 June, 1972. DMOK has a long term (1870-2014) mean of 01 June and standard deviation of 7-8 days. We have studied the inter-annual and decadal time scale variability of DMOK and their relation with SST. We found that SST anomalies of large spatial scale similar to those in El Nino/La Nina are associated with the inter-annual variability in DMOK. Indian Ocean between latitudes $5^{\circ} \mathrm{S}$ and $20^{\circ} \mathrm{N}$ has two episodes of active convection associated with monsoon onset over Kerala (MOK), one around DMOK and the other about six weeks earlier (called pre-monsoon rain peak or bogus monsoon onset) and in between a two week period of suppressed convection occurs over north Indian Ocean. A prominent decadal time scale variability was found in DMOK having large and statistically significant linear correlation with the SST gradient across the equator over Indian and Pacific oceans, the large correlation persisting for several months prior to the MOK. However, no linear trend was seen in DMOK during the long period from 1870 to 2014.

Keywords. Sea surface temperature (SST); outgoing long-wave radiation (OLR); date of monsoon onset over Kerala (DMOK); delayed and early monsoon onset; inter-annual and decadal variability in DMOK.

\section{Introduction}

Monsoon onset over Kerala (MOK) heralds the main rainy season in the Indian subcontinent. Monsoon onset is preceded by large scale changes in the atmosphere and ocean in the Indo-Pacific region (Ananthakrishnan et al. 1983; Pearce and Mohanty 1984; Ananthakrishnan and Soman 1988; Soman and Krishna 1993; Joseph et al. 1994, 2006). Climatologically monsoon sets in over the extreme south of India (Kerala) by the end of May. Accompanying the monsoon onset there is rapid increase in the daily rainfall of Kerala, vertically integrated moisture in the atmosphere and strength (kinetic energy) of the low level monsoon flow (Krishnamurti 1985).

One of the major parameters associated with the date of MOK (DMOK) is the sea surface temperature (SST) over the Indian and Pacific oceans. The centre of the warm pool of the tropical oceans gets 
shifted in the annual cycle from south-west Pacific to the north Indian Ocean from January to May (Joseph 1990a,b, 2014). The warm pool of May leads to a build-up of moisture in the atmosphere over north Indian Ocean and the adjoining Pacific Ocean over a month long period and makes conditions favourable for MOK (Pearce and Mohanty 1984; Joseph et al. 2006).

The long term mean date of MOK is 1 June. This date has varied widely over the years; the earliest was on 11 May in 1918 and the most delayed monsoon was on 18 June in 1972. Joseph et al. (1994) observed that prior to and during MOK dramatic changes occur in the atmosphere and oceans as described earlier (Pearce and Mohanty 1984; Krishnamurti 1985). Joseph et al. (1994) showed evidence that delays in MOK are associated with El Nino. Analysis of the SST field also showed that delayed MOK is associated with warm SST anomalies at and south of the equator in Indian and Pacific oceans and cold SST anomalies in the tropical and subtropical oceans to the north during the season prior to the monsoon onset (i.e., March-May). They hypothesized that such SST anomalies caused the inter-annual variability of MOK through their action in affecting the timing of the northward movement across the equator of the cloud band associated with the ITCZ. DMOK has been defined using different criteria that include rainfall, outgoing long wave radiation (OLR), lower tropospheric winds, etc. (Ananthakrishnan and Soman 1988; Joseph et al. 2006; Wang et al. 2009). India Meteorological Department (IMD) determined the date of MOK using a subjective method for more than 100 years as reviewed by Ananthakrishnan et al. (1967). Changes in rainfall and parameters like low level wind and moisture in the atmosphere were seen in a qualitative way to arrive at a subjective estimate of the date of MOK. At MOK rainfall has to be widespread spatially over Kerala and persistent for a few days. In 2006 IMD adopted an objective criteria for declaring MOK using criteria derived by Joseph et al. (2006) (as adopted by Pai and Rajeevan 2009) based on daily rainfall of Kerala, the depth of westerlies in a box (equator to latitude $10^{\circ} \mathrm{N}$ and longitude $55-80^{\circ} \mathrm{E}$ ), the zonal wind speed over the area bounded by latitude $5^{\circ}-10^{\circ} \mathrm{N}$ and longitude $70^{\circ}-80^{\circ} \mathrm{E}$ and mean OLR in the box latitude $5^{\circ}-10^{\circ} \mathrm{N}$ and longitude $70^{\circ}-75^{\circ} \mathrm{E}$. In both the subjective and objective methods, a sharp increase in rainfall of Kerala during MOK is important.
Li and Yanai (1996) showed that the onset of Asian summer monsoon is concurrent with the reversal of the meridional temperature gradient in the upper troposphere south of the Tibetan plateau. This reversal is the result of the large temperature increases in May-June over Eurasia centered on the plateau. The Tibetan heat source according to them is mainly contributed by the sensible heat flux from the ground surface. They however did not study the inter-annual variability of the date of monsoon onset. On the lines of their study Xavier et al. (2007) found that the meridional gradient of the tropospheric temperature (averaged between 600 and $200 \mathrm{hPa}$ ) is proportional to the meridional gradient of deep tropospheric heating and could lead to acceleration of the deep tropospheric circulation. Their objective definition of the large scale monsoon onset (over India and not Kerala) is based on the reversal of GrTT (Gradient in Tropospheric Temperature as average of 600 to $200 \mathrm{hPa}$ ) between a northern box $\left(40^{\circ}-100^{\circ} \mathrm{E}, 5-35^{\circ} \mathrm{N}\right)$ and a southern box $\left(40^{\circ}-100^{\circ} \mathrm{E}, 15^{\circ} \mathrm{S}-5^{\circ} \mathrm{N}\right)$ denoted by GrTT. The onset date (GrTT onset) is defined as the date when GrTT changes sign from negative to positive.

Fasullo and Webster (2003) used the vertically integrated moisture transport through India to define the date of monsoon onset over India (not Kerala). The authors claimed that their index is indicative of the transition in the large scale monsoon circulation over India. Joseph (2012) has compared the objective dates of monsoon onset over Kerala (Pai and Rajeevan 2009) with the monsoon onset dates over India as given by Xavier et al. (2007) and Fasullo and Webster (2003) using data of the period 1971-2000 and found the linear correlation coefficients between them are not large (0.59 and 0.56 respectively).

A very recent publication (Ordoñez et al. 2016) has given a method for and also derived objective dates for monsoon onset over Kerala using surface wind direction data collected by merchant ships plying over the Indian Ocean during the period 1877-2013, excluding several years where wind data was scarce, particularly, due to world wars. We have, later in this paper, compared this MOK dataset with IMD objective onset dates of the period from 1971.

In this paper we have constructed a long time series of the dates of MOK spanning the period from 1870 to 2014 using all available sources of data on MOK. Such a dataset is required to study the climate change during monsoon and its relation to 
the changes in the global atmosphere and oceans. We have, in particular, studied the inter-annual and decadal scale variability of the date of MOK and their relationship with SST over the Indian and Pacific oceans.

\section{Data used}

The onset dates for north Kerala from 1870 to 1900 were taken from Ananthakrishnan and Soman (1989) and for the period 1901-1970 from Ananthakrishnan and Soman (1988). These are objectively determined dates, using only the daily average rainfall of a network of rain-gauge stations in north Kerala. The objective dates of MOK from 1971 to 2005 were taken from Pai and Rajeevan (2009) and for the later years till 2014 from the annual monsoon reports published by IMD in their journal Mausam. We have thus a long dataset of the date of monsoon onset for north Kerala and Kerala for the period 1870-1900 and 1901-2014, respectively. Such a long dataset will be very useful for climate change studies. These dates are given in table 1. Their 11-year moving averages are given in figure 1(a). During the period 1901-1980, we have onset dates for north Kerala by Ananthakrishnan and Soman (1988) and for whole Kerala the subjective onset dates as derived by IMD. For this period, the mean difference in onset dates between these two series is one day, north Kerala onset, date being the earlier one. For declaring monsoon onset, IMD's subjective criteria stipulates two consecutive days of rainfall over Kerala and onset is declared on the second day. Thus there is really no difference in the onset dates of these two series. To get a long series for the onset dates over Kerala (DMOK) for the period 1870-2014, we have adopted the following method. For the period 1870-1900, we have added 1 to the onset dates for north Kerala as derived by Ananthakrishnan and Soman (1989). We have taken the subjective onset dates for Kerala as derived by IMD for the period 1901-1970. To this we have added the objective dates of MOK as derived by IMD of the period 1971 to 2014. This long time series of DMOK is represented by the red bars in figure 1(b) and their 11-year moving average by the black line. The statistical properties of above-mentioned series is given in table 3 . The SST gradient in IndoPacific region during the season March-April also reflects a similar pattern of inter-annual variability of DMOK is presented in figure 1(c). The mean
DMOK for 1870-2014 is June 1st and the standard deviation (SD) is around 7 days. Those who use this long dataset for climate change studies should know that the onset dates of the period 1870-1970 have not been corrected for bogus onset occurrences. Onset dates of this period have been derived without using low level wind or satellite data which are needed for the whole Indian Ocean basin to identify pre-monsoon rain peak or bogus monsoon onset (which occurs once in about 10 years) as described in Joseph et al. (2006). In this connection, a study by Sabeerali et al. (2012) on the withdrawal dates is relevant and they observed a clear shift prior (posterior) to the 1976/77 climate shift; most of the withdrawal dates are associated with a late (early). However, we did not notice any shift in onset dates.

The objective dates of MOK derived by IMD is from 1971. Ordoñez et al. (2016) have derived a method to eliminate bogus onset dates of monsoon using surface wind direction as recoded by merchant ships plying in Indian Ocean. We compared the MOK dates derived by them (called ship wind data) with the objective MOK dates derived by IMD. The difference between these dates (IMD objective onset dates - ship wind onset dates) is positive in most of the years and large positive in several years as may be seen in table 2. We are therefore unable to use this dataset to derive a long dataset of objective MOK dates.

Monthly mean SST data from 1870 to 2014 was obtained from HadISST datasets (Rayner et al. 2003). The OLR data has been taken from National Oceanic and Atmospheric Administration (NOAA) and is available from June 1974 to present, except for 1978 when the data is missing due to satellite problems (Liebmann and Smith 1996). The data is interpolated in space to remove the effect of missing values. The OLR data is mapped onto a $2.5^{\circ} \times 2.5^{\circ}$ grid size, which represented an average of OLR values twice daily (one daytime and one night time) as the satellite passes. National Oceanic and Atmospheric Administration (NOAA) Optimum Interpolation SST (OISST) Version 2 dataset (Reynolds et al. 2007) data (September 1981 to present) have been made available by the NOAA Earth System Research Laboratory Physical Science Division (ESRL/PSD) through their website at http://www.esrl.noaa.gov/psd/. These are daily SST records (one daily value for each pixel), with spatial resolution of $0.250 \times$ 0.250, based on the Advanced Very High Resolution Radiometer (AVHRR) infrared satellite 


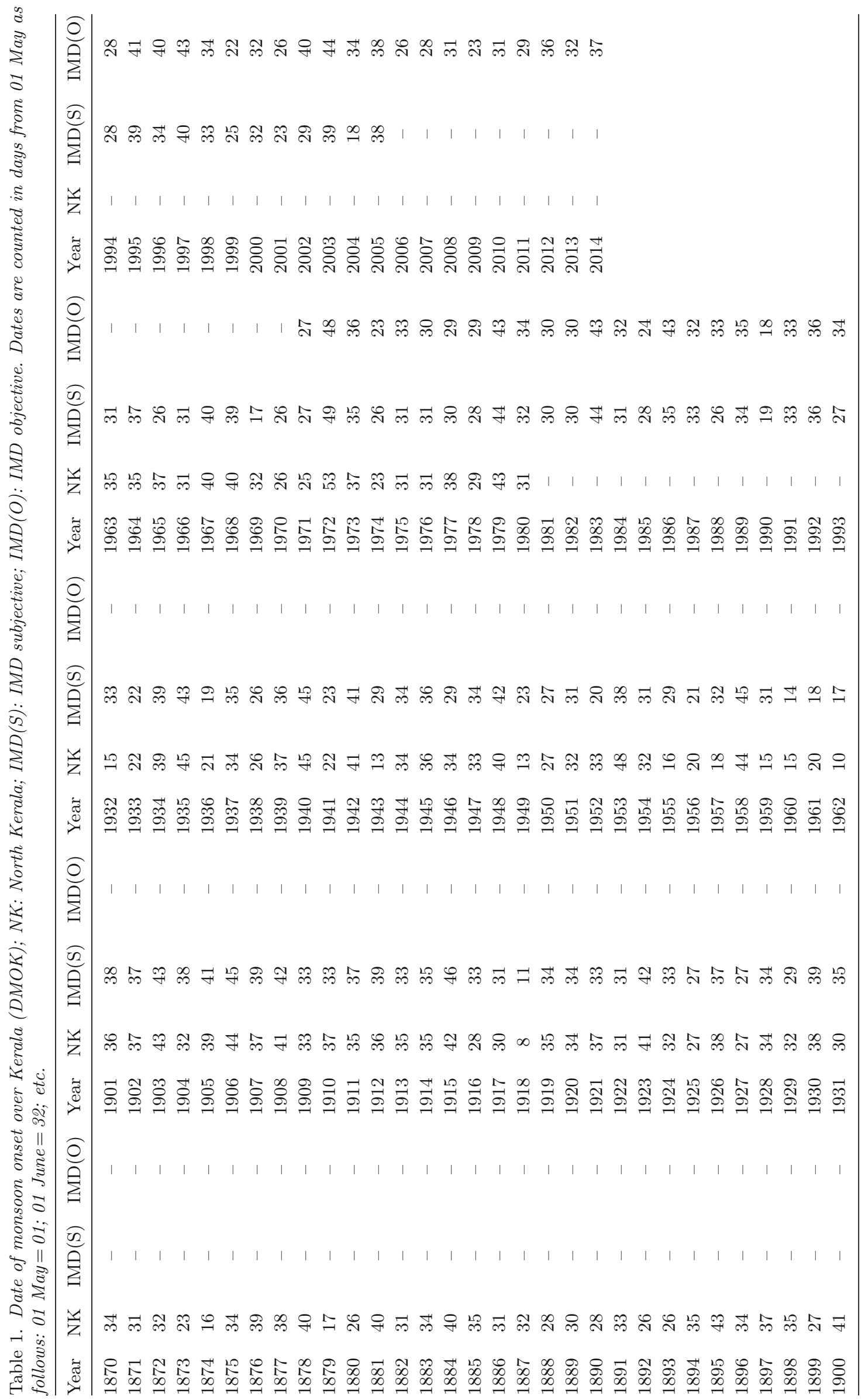



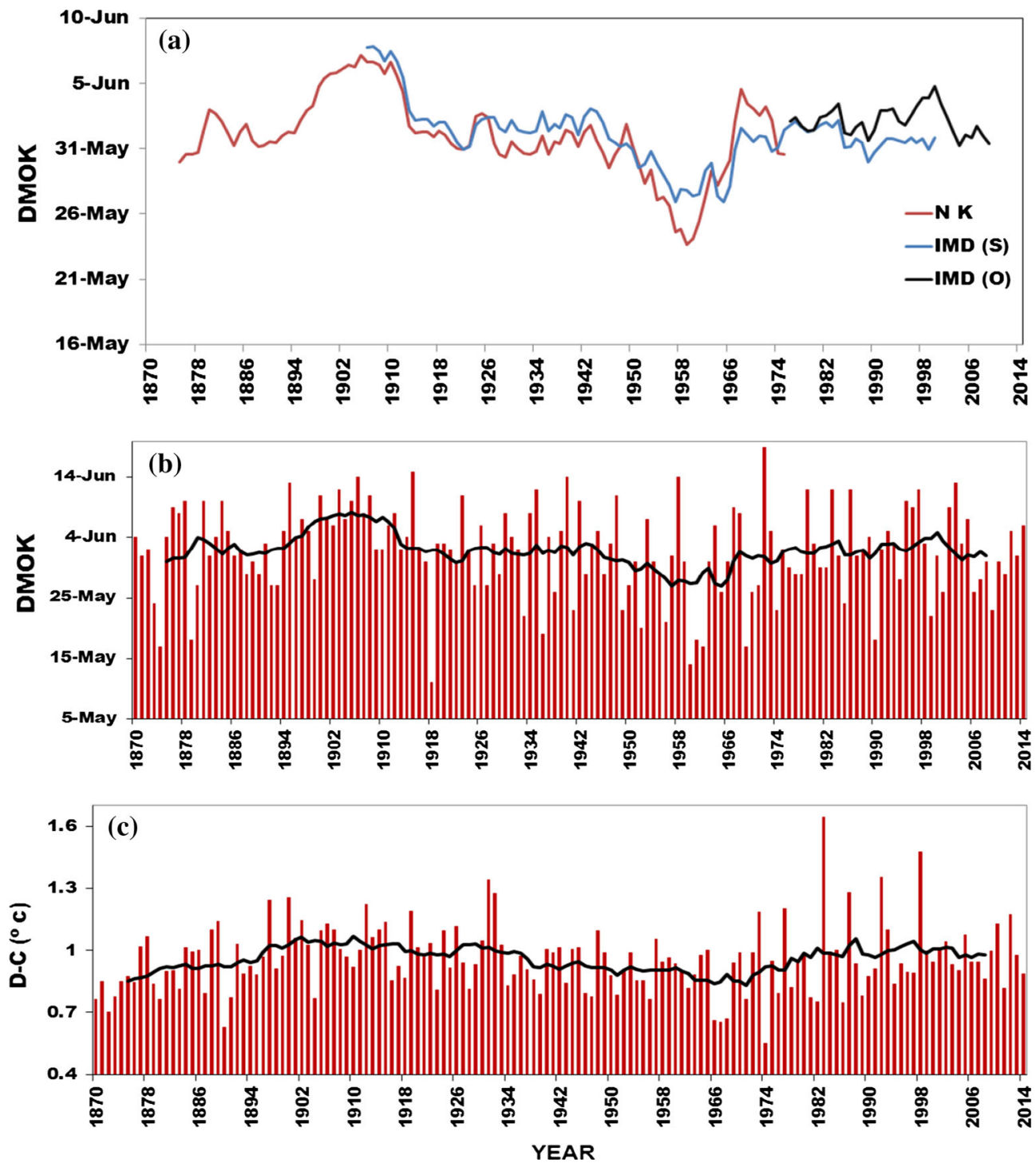

Figure 1. (a) 11-year moving averages of dates of monsoon onset over north Kerala, IMD monsoon onset over Kerala (subjective) and IMD monsoon onset over Kerala (objective). (b) Date of monsoon onset over Kerala for the period 18702014 combining the three series given at (a) is shown in red bars and their 11-year moving average is marked by black line. (c) SST difference for each year of $1870-2014$ between the latitude-longitude boxes $30^{\circ}-270 \mathrm{E}, 0-20 \mathrm{~S}(\mathrm{D})$ and $30^{\circ}-270^{\circ} \mathrm{E}$, $5^{\circ}-20^{\circ} \mathrm{N}$ (C) for the season March-April and its 11-year moving averages.

measurements. The ENSO index is based on the SST anomalies averaged in the Niño3.4 region $\left(170^{\circ}-120^{\circ} \mathrm{W}, 5^{\circ} \mathrm{S}-5^{\circ} \mathrm{N}\right)$. The 'Dipole Mode Index' (DMI) is based on the SST anomalies in $50^{\circ}-70^{\circ} \mathrm{E}$, $10^{\circ} \mathrm{S}-10^{\circ} \mathrm{N}$ minus those in $90^{\circ}-110^{\circ} \mathrm{E}, 10^{\circ} \mathrm{S}-0^{\circ} \mathrm{N}$ (Saji et al. 1999).

\section{Inter-annual variability of MOK and its relation with SST anomalies}

SST plays a vital role in the timing of monsoon onset over Kerala (Joseph et al. 1994, 2006; Joseph 2014). SST anomalies on either side of equator in Indian and Pacific oceans are found to be related to the date of MOK. In our study, MOK is considered as delayed if it has occurred eight days or more (one standard deviation) after 01 June. Similarly, if MOK is eight days or more before 01 June, it is defined as early. Joseph (2014) found the linear correlation coefficient (LCC) between the objective dates of MOK and the SST using 30 years of data (1971-2000). We have used longer period data and found the LCC between IMD's objective DMOK and SST of January-February and MarchApril for the period 1971-2014 which is given in figure 2. The LCCs are high and statistically significant over large spatial areas marked by the blue lines in the figure which gives correlation coefficient of 0.3 which is significant at $95 \%$ level using t-test. 
Table 2. Difference (in days) between the DMOKs (IMD objective minus ship wind) of each year 1972 to 2005.

\begin{tabular}{|c|c|c|c|c|}
\hline \multirow[b]{2}{*}{-5 and below } & \multicolumn{4}{|c|}{ IMD objective onset date minus ship wind onset date } \\
\hline & $-4,-3,-2$ & $-1,0,+1$ & $+2,+3,+4$ & +5 and above \\
\hline & 1982 & 1974,1987 & 1975,1977 & 1972 (06 days) \\
\hline & & 1992,2005 & 1979,1983 & 1973 (10 days) \\
\hline & & & 1984,1985 & 1976 (05 days) \\
\hline & & & 1988,1990 & 1978 (10 days) \\
\hline & & & 1991,1993 & 1980 (06 days) \\
\hline & & & 1994,1997 & 1981 (05 days) \\
\hline & & & 1998 & 1986 (06 days) \\
\hline & & & & 1989 (11 days) \\
\hline & & & & 1995 (07 days) \\
\hline & & & & 1996 (06 days) \\
\hline & & & & 1999 (10 days) \\
\hline & & & & 2000 (18 days) \\
\hline & & & & 2001 (08 days) \\
\hline & & & & 2002 (17 days) \\
\hline & & & & 2003 (08 days) \\
\hline & & & & 2004 (21 days) \\
\hline & 1 year & 4 years & 13 years & 16 years \\
\hline
\end{tabular}

MOK is delayed when the SST anomaly is positive at south of the equator and negative at north of it. This correlation pattern was also persistent for several months prior to MOK. The LCC patterns over the Pacific and Indian oceans show that delayed MOK is associated with El Nino whereas an early MOK is associated with La Nina. The association of delayed MOK with El Nino has been shown by Joseph et al. (1994). The composite SST anomalies of January-February and March-April of delayed and early DMOK years of the period 1901-2014 are given in figure 3. According to the study by Joseph et al. (1994), monsoon onset delays occur in El Nino (0) year and more often in El Nino $(+1)$ year. During the period 1870-2014, there were 21 cases of monsoon onset delays of one standard deviation or more and 13 out of these 21 cases have occurred in El Nino(0) or $(+1)$ year (table 4$)$. For compositing, the SST anomalies were derived by subtracting an 11-year mean SST centered over the year for each case. The SST anomalies are similar to those derived from the correlation study in figure 2. Further, we computed first EOF mode of SST over Indo-Pacific domain and this mode depict El Nino related SST anomaly in Pacific (figure 4). The time series of this anomaly has statistically significant correlation of 0.2 with the monsoon onset dates of 1870-2014, for the January-February season. For the March-April season, the correlation is smaller. However, the correlation between dates
Table 3. Mean and Standard deviation of different series.

\begin{tabular}{lcc}
\hline Series & Mean & SD \\
\hline NK: 1870 to 1900 & 01 June & 6.5 days \\
IMD(S): 1901 to 1970 & 01 June & 7.9 days \\
IMD(O): 1971 to 2014 & 01 June & 6.7 days \\
NK+1: 1870 to $1900+$ & 01 June & 7.2 days \\
IMD(S): 1901 to $1970+$ & & \\
IMD(O): 1971 to 2014 & & \\
NK: North Kerala; IMD(S): & IMD & subjective; \\
IMD(O): IMD objective. & &
\end{tabular}

of monsoon onset and Nino 3.4 index of JanuaryFebruary and March-April seasons are statistically significant at $95 \%$ level (figure 5). The correlation between dates of monsoon onset and IOD index (figure not shown) is also tested but is not significant. The spatial pattern of EOF-1 shows that in delayed onset years there is warm SST anomaly south of the equator in Indian and Pacific oceans. EOF-1 is similar to the figure showing the correlation between date of monsoon onset and SST as shown in figure 2 .

\section{Evolution of OLR in delayed and early MOK}

As described in Introduction, the center of the warm pool (area of maximum SST) shifts in the annual cycle from southwest Pacific Ocean to north 

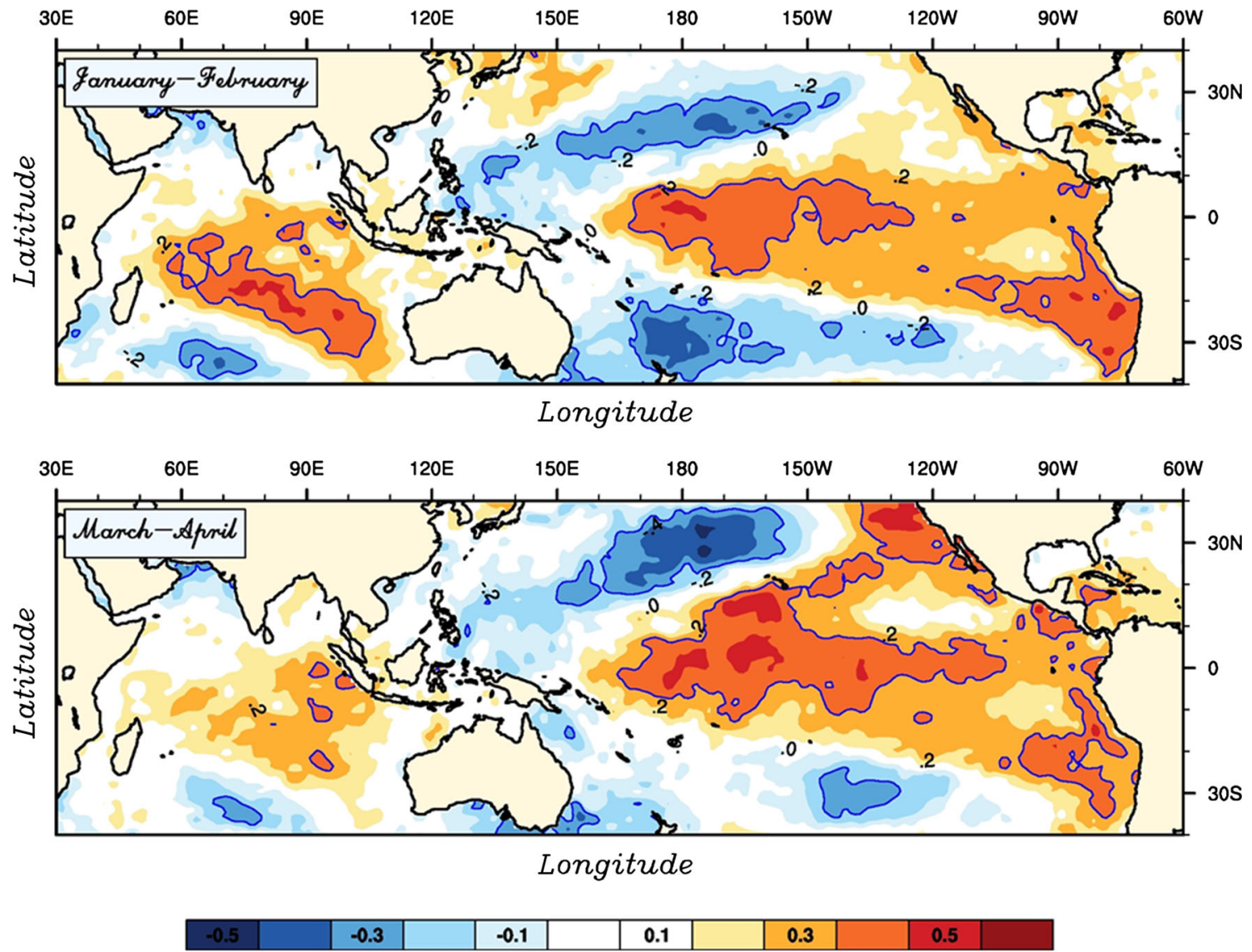

Figure 2. Linear correlation coefficient between HadISST and IMD's objective dates of MOK from 1971 to 2014 for JanuaryFebruary (above) and March-April (below). The significant values are marked by thick blue line. Linear correlation coefficient is 0.3 for a significance level of $95 \%$ by a t-test and $r=0.3$ is marked by a blue line.

Indian Ocean from January to May. But there is a fine structure to the changes in SST and the associated convection (OLR) in Northern Indian Ocean prior to MOK. The fine structure of the changes in SST for the MOK of 2003 is described in Joseph (2014). SST of north Indian Ocean reaches maximum first over the Bay of Bengal, about 7-8 pentads before the date of MOK, when SST reaches high values of $31^{\circ} \mathrm{C}$ or even $32^{\circ} \mathrm{C}$ in central Bay of Bengal. To the south of the region of this SST maximum, in the area of large SST gradient, deep convection develops and grows in area and intensity. The latent heat released in this convective area heats the atmosphere there and generates strong cross equatorial low level wind flow. The convective clouds and the low level winds cool the Bay of Bengal. When these changes are happening in the Bay of Bengal, Arabian Sea has much lower SST with very little convection and only feeble low level winds which make the SST of Arabian Sea warm rapidly. About three pentads before MOK, SST over central Arabian Sea reaches $31^{\circ} \mathrm{C}$ or $32^{\circ} \mathrm{C}$ and in the SST gradient area south of this region convection and strong low level winds develop the northward movement which brings about monsoon onset over Kerala.

We studied the evolution of convection (OLR) prior to MOK for the delayed and early monsoon onset years. Composite pentad OLR charts are made for the delayed onset years $(1979,1983,1986$, 1995, 1996, 1997, 2002 and 2003) and for the early onset years (1974, 1985, 1990, 1999 and 2009) for several pentads prior to MOK with MOK taken as occurring around zero pentad.

Figure 6(a) shows the composite mean pentad variations in the OLR of delayed onset years of the period 1974-2014 (see table 4). Zero pentad is that of monsoon onset over Kerala. Coinciding with pentad-10 (22-26 April) there is deep convection (low values of OLR) around equatorial Bay of Bengal extending to the west Pacific Ocean. This band of convection increases in size and moves north up to pentad-7 (07-11 May); when its left-most portion brings rain over Kerala. This has been called pre-monsoon rainfall peak (PMRP) by Joseph and Pillai (1988) and 'bogus 

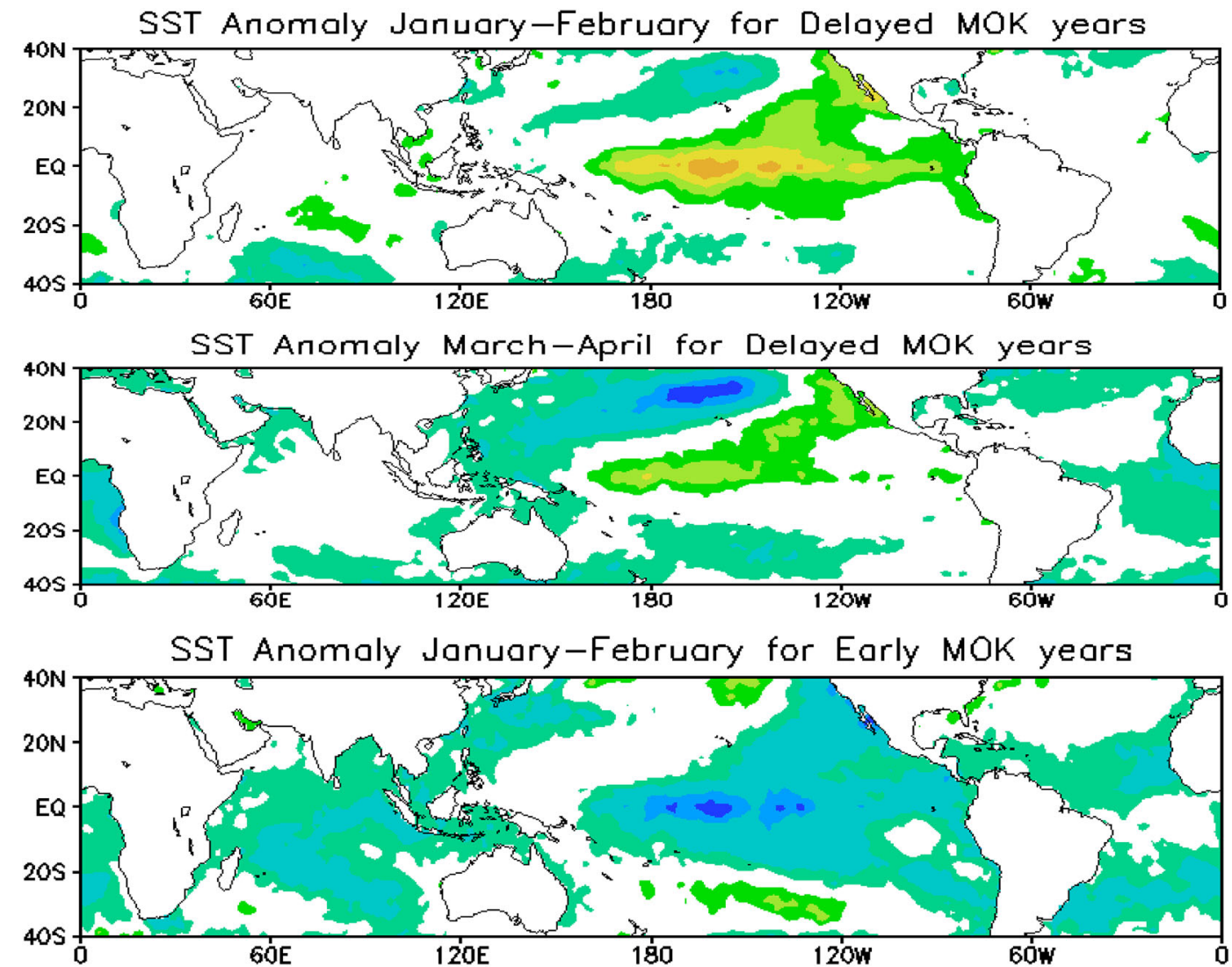

SST Anomaly March-April for Early MOK years
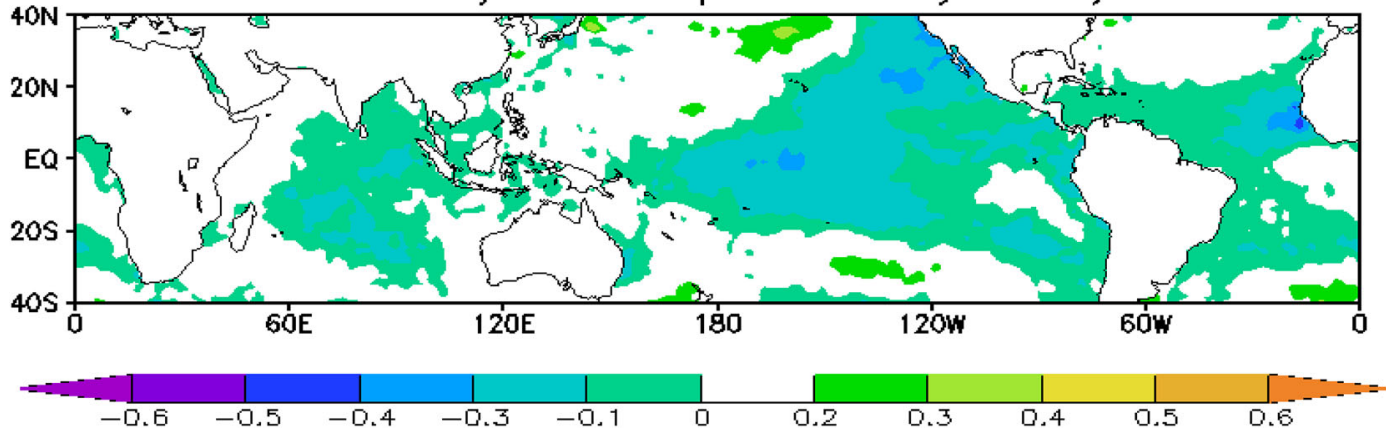

Figure 3. The composite SST anomaly of the January-February and March-April of delayed and early DMOK years of the period 1901-2014.

Table 4. Years of delayed monsoon onset over Kerala (MOK) during 1901-2014. The El Nino year is marked by (0) and the following year by $(+1)$.

\begin{tabular}{lll}
\hline \multicolumn{3}{c}{ Years of delayed MOK } \\
\hline $1903(+1)$ & $1940(0)$ & $1983(+1)$ \\
$1905(0)$ & $1942(+1)$ & $1986(0)$ \\
1906 & 1948 & $1995(+1)$ \\
1908 & $1958(+1)$ & 1996 \\
1915 & 1967 & $1997(0)$ \\
$1923(0)$ & $1972(0)$ & $2002(0)$ \\
1935 & 1979 & $2003(+1)$ \\
\hline
\end{tabular}

monsoon onset' by Flatau et al. (2001) associated with strong low level winds. Soon after the PMRP, the band of convection moves northeastward to usher in monsoon onset in some years over the Indo-China peninsula at pentads- 6 and -5 as shown by Joseph et al. (2006). At pentad-4 (22-26 May), the OLR field suggests that Indian Ocean is practically free of convection. At pentad-3 (27-31 May) a fresh elongated narrow band of convection formed close to the equator (in the Indian Ocean south of Arabian Sea). This band of convection grows rapidly in intensity and area as seen by the OLR of pentads-2 (01-05 June) and -1 (06-10 June), bringing about the monsoon onset over Kerala at zero pentad (11-15 June).

The composite mean OLR for early onset years for selected pentads is given in figure $6(\mathrm{~b})$. The 


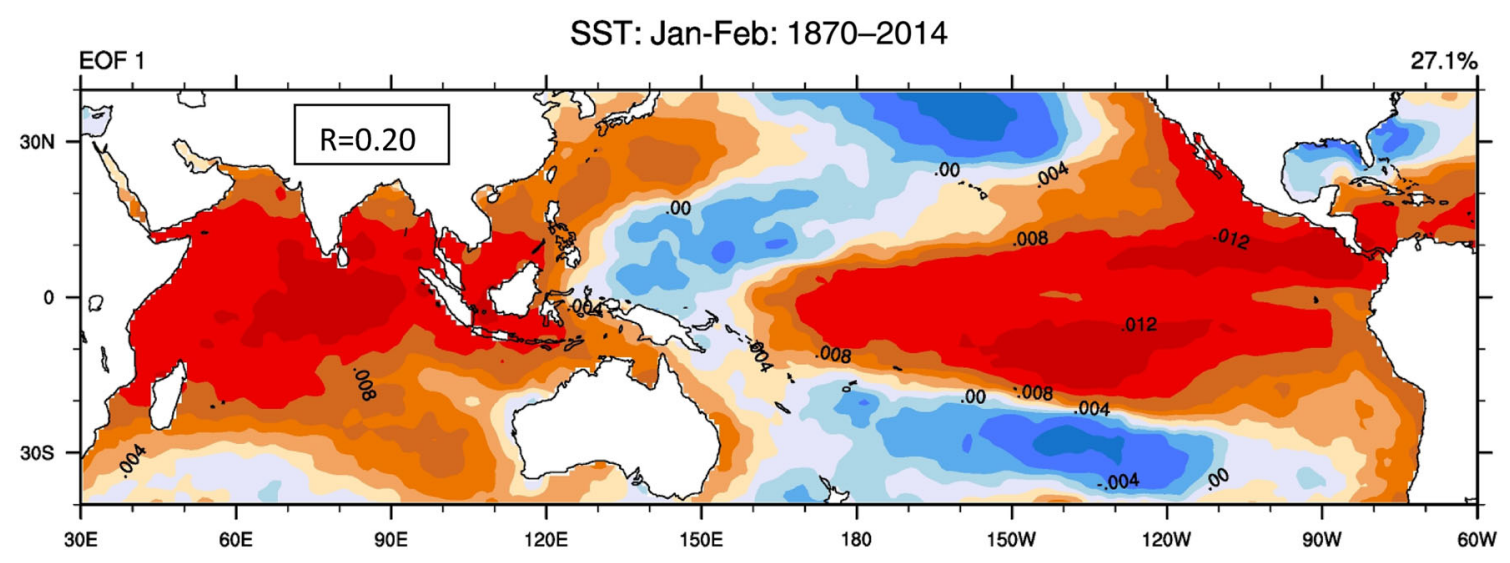

SST: Mar-Apr: 1870-2014

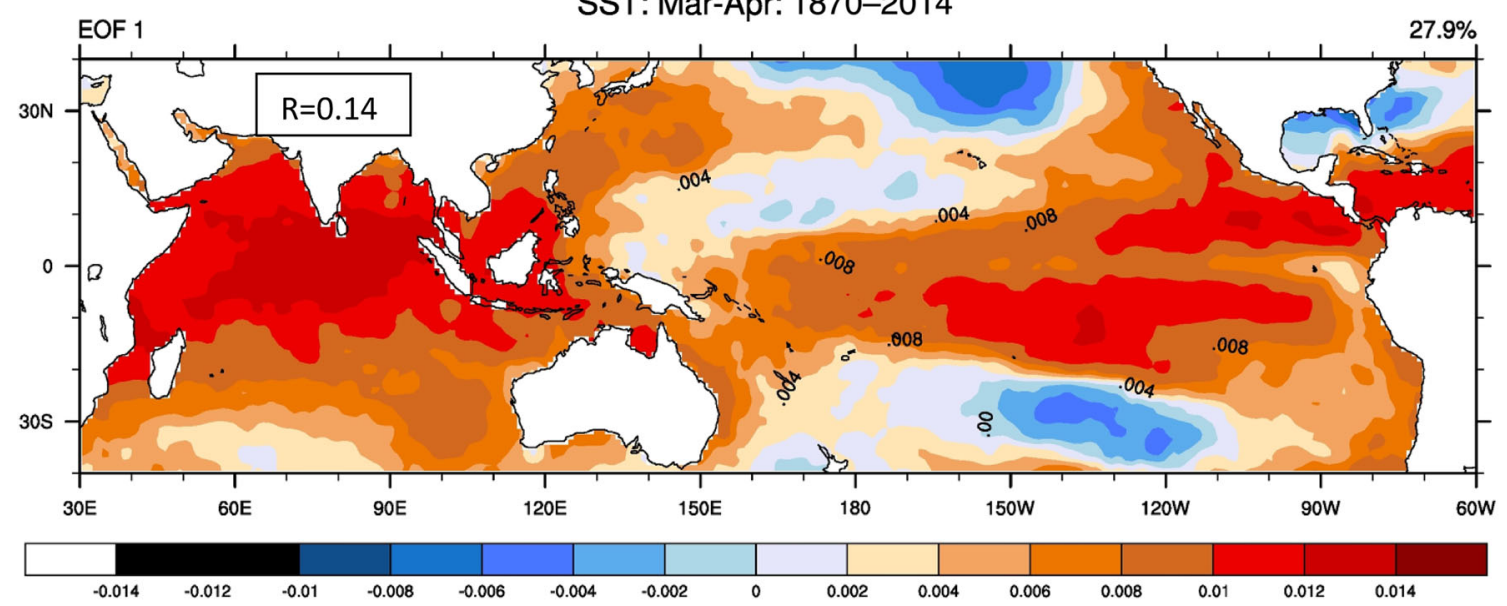

Figure 4. EOF1 of SST over Indo-Pacific domain for the seasons January-February (above) and March-April (below). The correlation of time series of first PC (principal component) with monsoon onset dates are marked by $\mathrm{R}$.

development and migration of the convection bands for the early MOK years is similar pentad-wise to delayed MOK years but the PMRP and MOK are found to occur four pentads earlier date-wise. Thus PMRP for early MOK composite is on pentad 7-11 April and MOK on pentad 22-26 May. We also constructed composite OLR charts for normal onset years (figure not shown). The pentad-wise evolution of OLR with zero pentad taken as DMOK is the same as for late and early onset composites. These three composites show that there is a minimum of convection in north Indian Ocean during pentads- $5,-4$ and -3 .

\section{Why convection occurs in Bay of Bengal earlier than Arabian Sea?}

A question arises as to why SST reaches maximum in the annual cycle January-May, first in Bay of Bengal followed by Arabian Sea nearly a month later. Figure $7(\mathrm{a}, \mathrm{b})$ gives the monthly mean
SST averaged over the period 1974-2014 for the months of March and April. The axis of maximum SST is oriented from south-west to north-east (in west Indian Ocean, the SST maximum is close to the equator and in the east Indian Ocean it is at about latitude $10^{\circ} \mathrm{N}$ ). It is speculated that this south-west to north-east orientation is taken by the axis of SST maximum due to the strong cooling of SST of the Arabian Sea during the previous monsoon season. The strong low level winds of the monsoon are known to cool the Arabian Sea by causing coastal and open ocean upwelling and by evaporative cooling of the ocean surface. Figure 8(a) shows the day-to-day change of the mean SST of the Bay of Bengal Box (red curve) bounded by latitudes $10^{\circ}-20^{\circ} \mathrm{N}$ and longitudes $85^{\circ}-95^{\circ} \mathrm{E}$ and the Arabian Sea box (blue curve) bounded by latitudes $10^{\circ}-20^{\circ} \mathrm{N}$ and longitudes $60^{\circ}-70^{\circ} \mathrm{E}$. Bay of Bengal box reaches SST maximum first around mid-April whereas the Arabian Sea box reaches SST maximum about a month later. We have also represented this by a Hovmöller diagram showing 

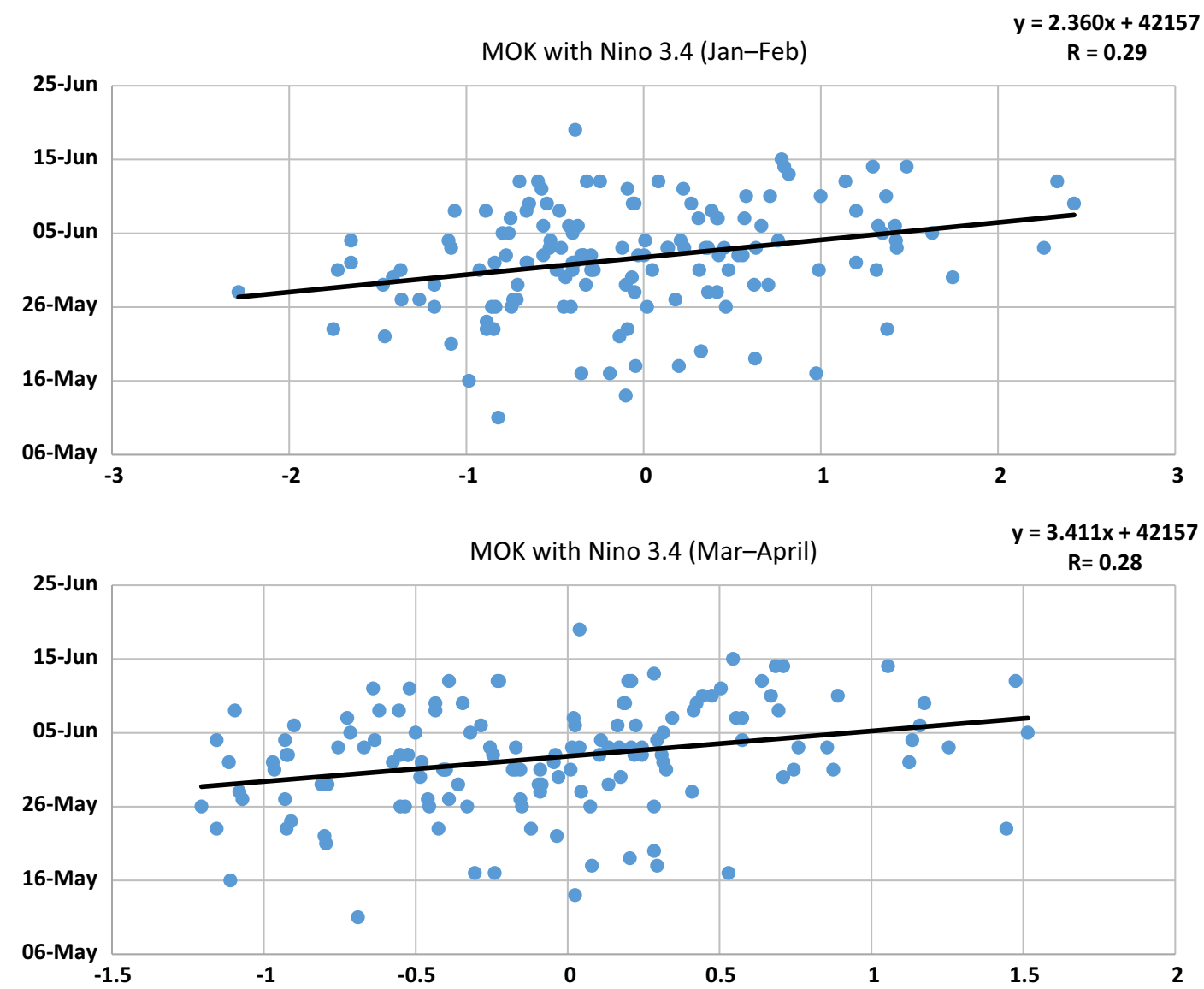

Figure 5. Correlation between dates of monsoon onset and Nino 3.4 index of January-February (above) and March-April (below).

the time latitude change of the mean SST averaged over the longitudes $85^{\circ}-95^{\circ} \mathrm{E}$ over the Bay of Bengal (figure $8 \mathrm{~b}$ ) and $60^{\circ}-70^{\circ} \mathrm{E}$ over the Arabian Sea (figure 8c).

\section{Decadal variability in the date of MOK}

Figure 1(b) gives date of MOK from 1870 to 2014. It can be seen that in the beginning of last century, in many years of the decades 1900s and 1910s, MOK was delayed by one to two weeks, whereas in the middle of the last century, in many years of the decades 1950s and 1960s, MOK occurred early by one or two weeks. The mean date of MOK for the period 1900-1920 is 05 June with a standard deviation of 7.2 days. Similar values for the period 1950-1970 are 26 May and 8.5 days, respectively. The difference in the mean dates of MOK for these two 21-year periods is statistically significant at the 99\% level as per t-test. Thus on a decadal scale, there has been a statistically significant change in the date of MOK during the last 150 years.
There is, however, no linear trend for this long time series.

In order to study the influence of SST in the decadal time scale variability of DMOK, we selected five boxes (A-E) over the oceans surrounding the equator as given in table 5 . The LCC between 11-year moving averages of SST gradient across the equator and MOK of pairs of these boxes is shown in table 6 . The boxes $\mathrm{A}\left(30^{\circ}-120^{\circ} \mathrm{E}\right.$, $\left.5^{\circ}-20^{\circ} \mathrm{N}\right)$ and $\mathrm{B}\left(30^{\circ}-120^{\circ} \mathrm{E}, 0-20^{\circ} \mathrm{S}\right)$ represent areas north and south of the equator in the Indian Ocean. The LCC between 11-year moving average of SST gradient and MOK in these boxes during January and February (0.23) which increased to 0.58 during March and April. Similar values for the boxes $\mathrm{C}\left(30^{\circ}-270^{\circ} \mathrm{E}, 5^{\circ}-20^{\circ} \mathrm{N}\right)$ and $\mathrm{D}$ $\left(30^{\circ}-270^{\circ} \mathrm{E}, 0-20^{\circ} \mathrm{S}\right)$ representing north and south tropical Indian and Pacific oceans have the maximum LCC compared to all other LCC. They are 0.63 and 0.67 respectively. Figure $1(\mathrm{c})$ gives SST difference (gradient) for March and April every year during 1870-2014 between the latitudelongitude boxes $\mathrm{C}\left(30^{\circ}-270^{\circ} \mathrm{E}, 5^{\circ}-20^{\circ} \mathrm{N}\right)$ and $\mathrm{D}$ 

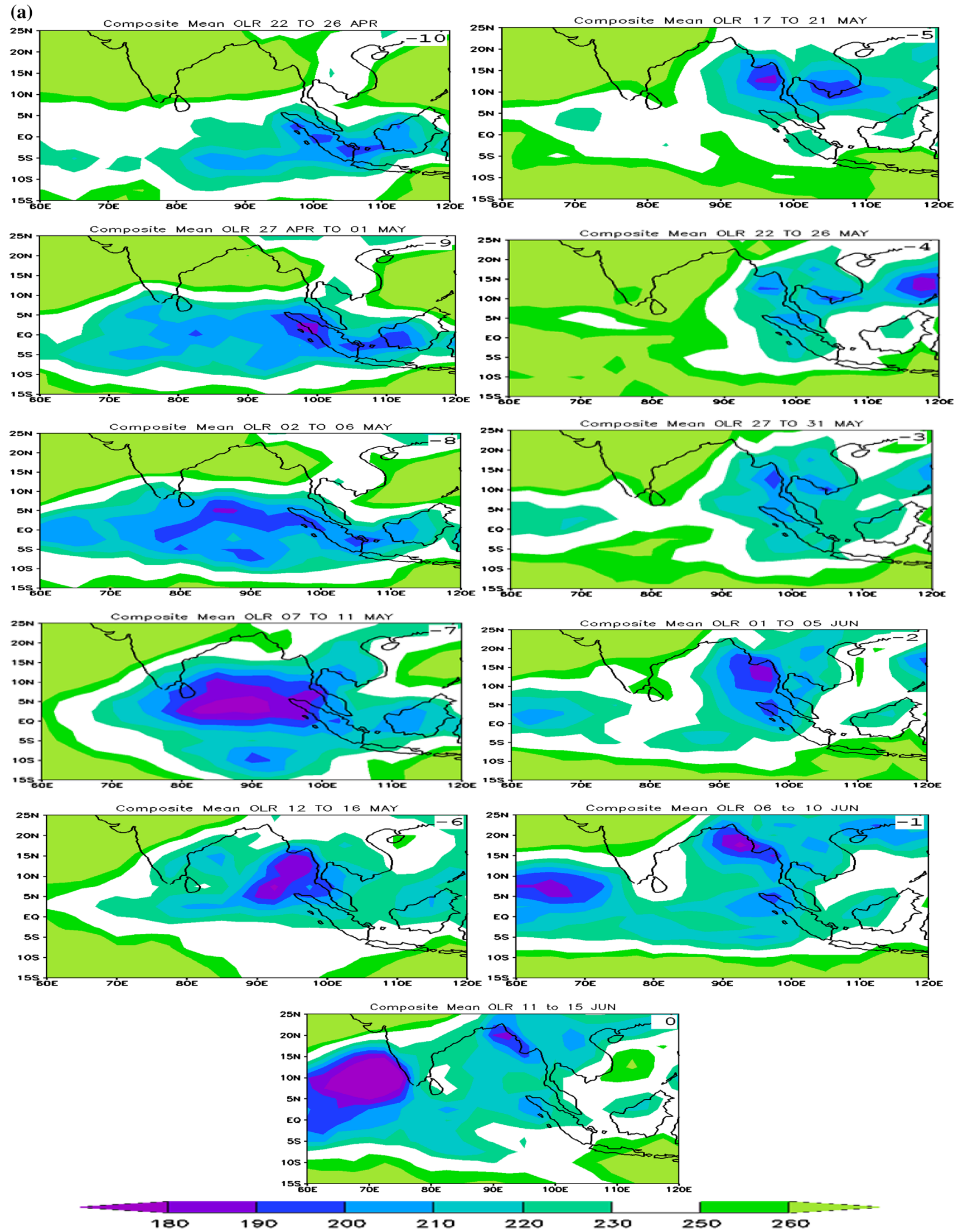

Figure 6. (a) The composite mean OLR $\left(\mathrm{Wm}^{-2}\right)$ for delayed MOK years $(1979,1983,1986,1995,1996,1997,2002$ and 2003) (pentads marked on top right corner, MOK is taken as zero pentad). (b) The composite mean OLR (Wm ${ }^{-2}$ ) for early MOK years (1974, 1985, 1990, 1999 and 2009) (pentads marked on top right corner, MOK is taken as zero pentad). 

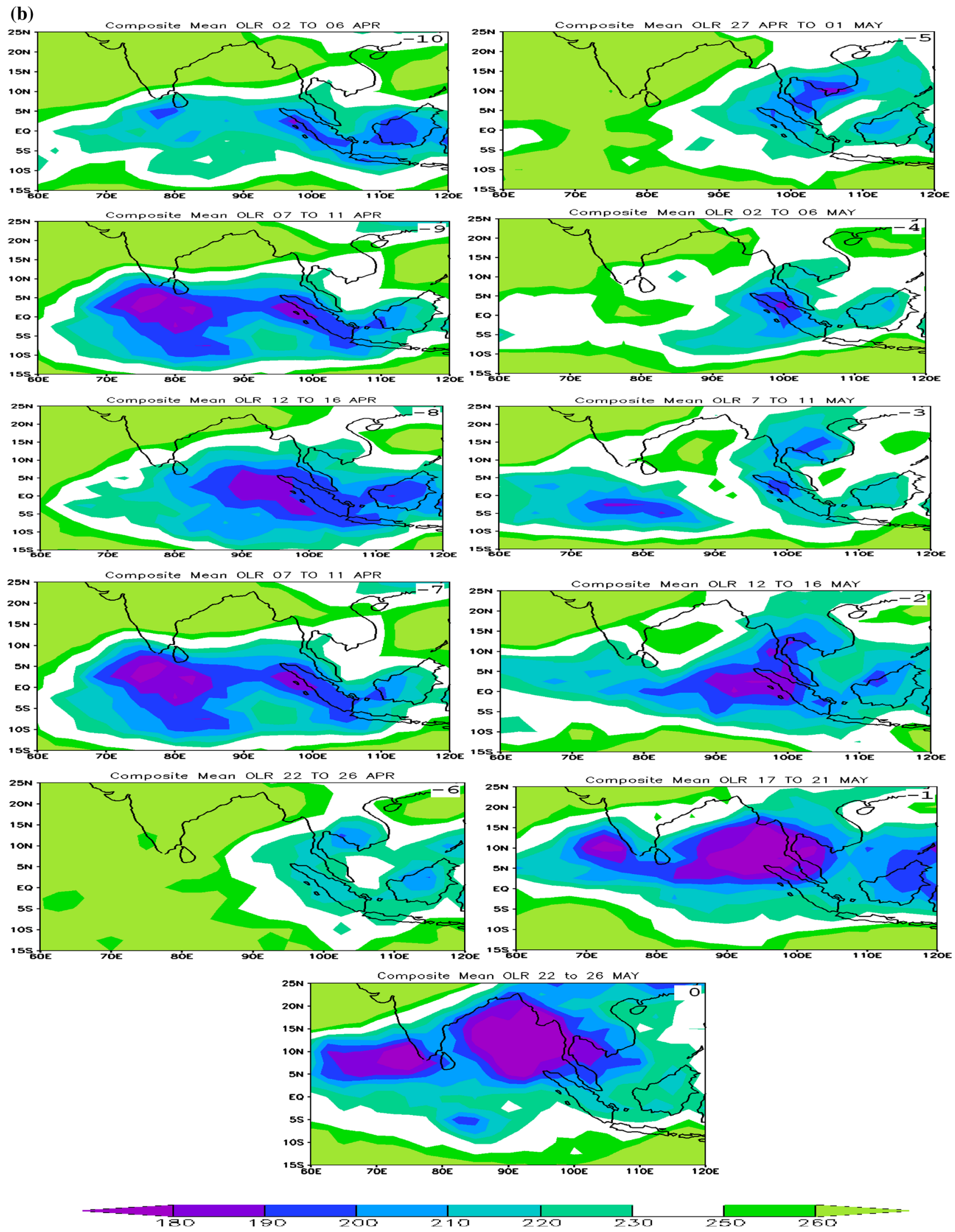

Figure 6. (Continued.) 

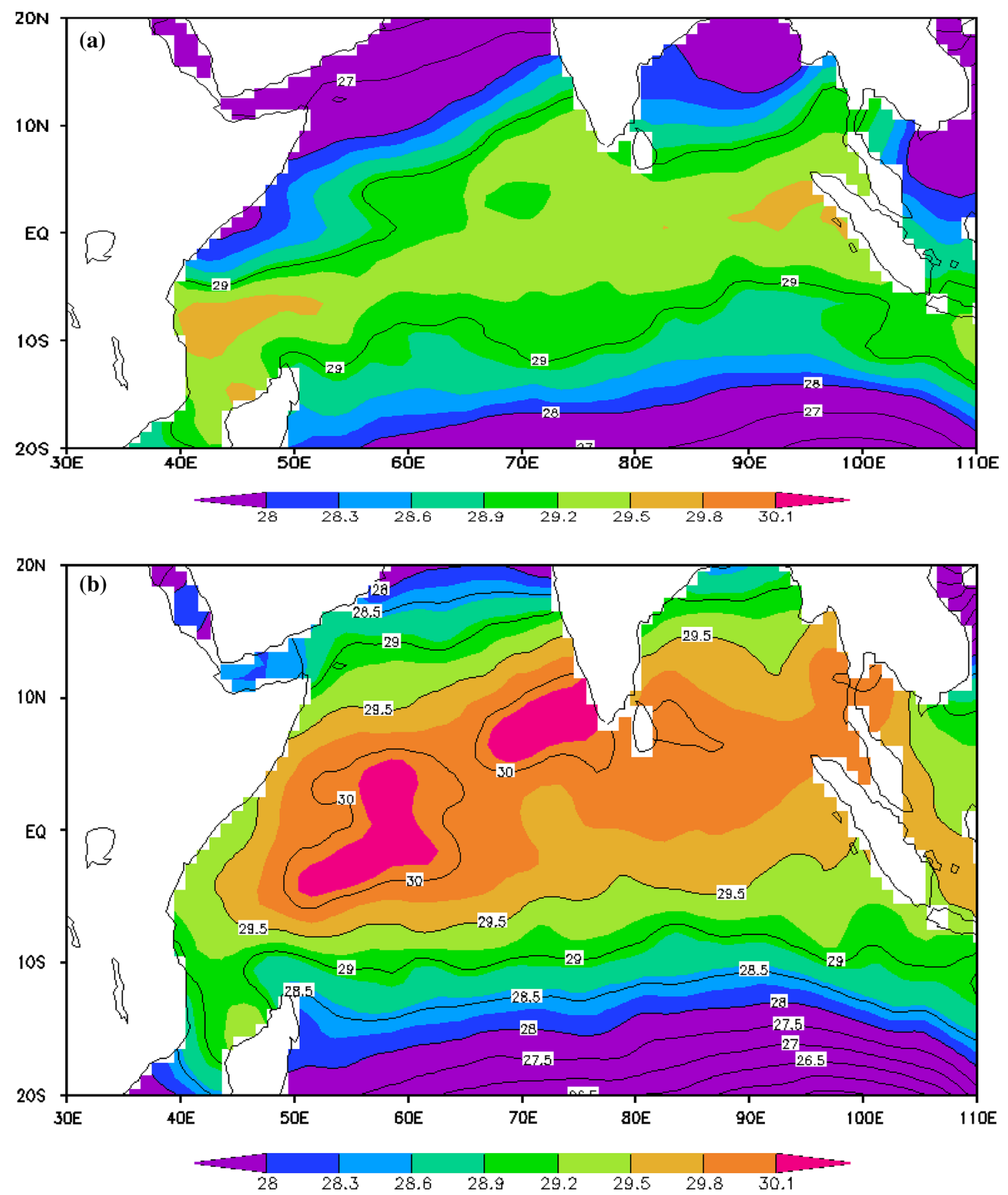

Figure 7. (a) Mean SST $\left({ }^{\circ} \mathrm{C}\right)$ (1974-2014) for the month March. (b) Mean SST $\left({ }^{\circ} \mathrm{C}\right)(1974-2014)$ for the month April.

$\left(30^{\circ}-270^{\circ} \mathrm{E}, 0-20^{\circ} \mathrm{S}\right)$ with the 11 -year moving average marked. The mean of SST gradient between these boxes for period 1900-1920 is 1.04 with an SD of 0.13 in the season March and April. Similar values for the period $1950-1970$ are 0.88 and 0.12 respectively. The difference in the mean SST for these two periods is statistically significant at $99 \%$ level as per t-test. The LCC of 0.67 between the 11-year moving averages during March-April SST gradient and the date of MOK for the period 1870-2014 is large and statistically significant. Similarly, the LCC for the JanuaryFebruary SST gradient is 0.61 which is also large. Both the correlations are statistically significant at $99 \%$ level. In the introduction it was mentioned that the center of the warm pool of the tropical oceans gets shifted in the annual cycle from southwest Pacific to the north Indian Ocean during January-May (Joseph 1990a, b, 2014) and the warm pool of May leads to a build-up of 

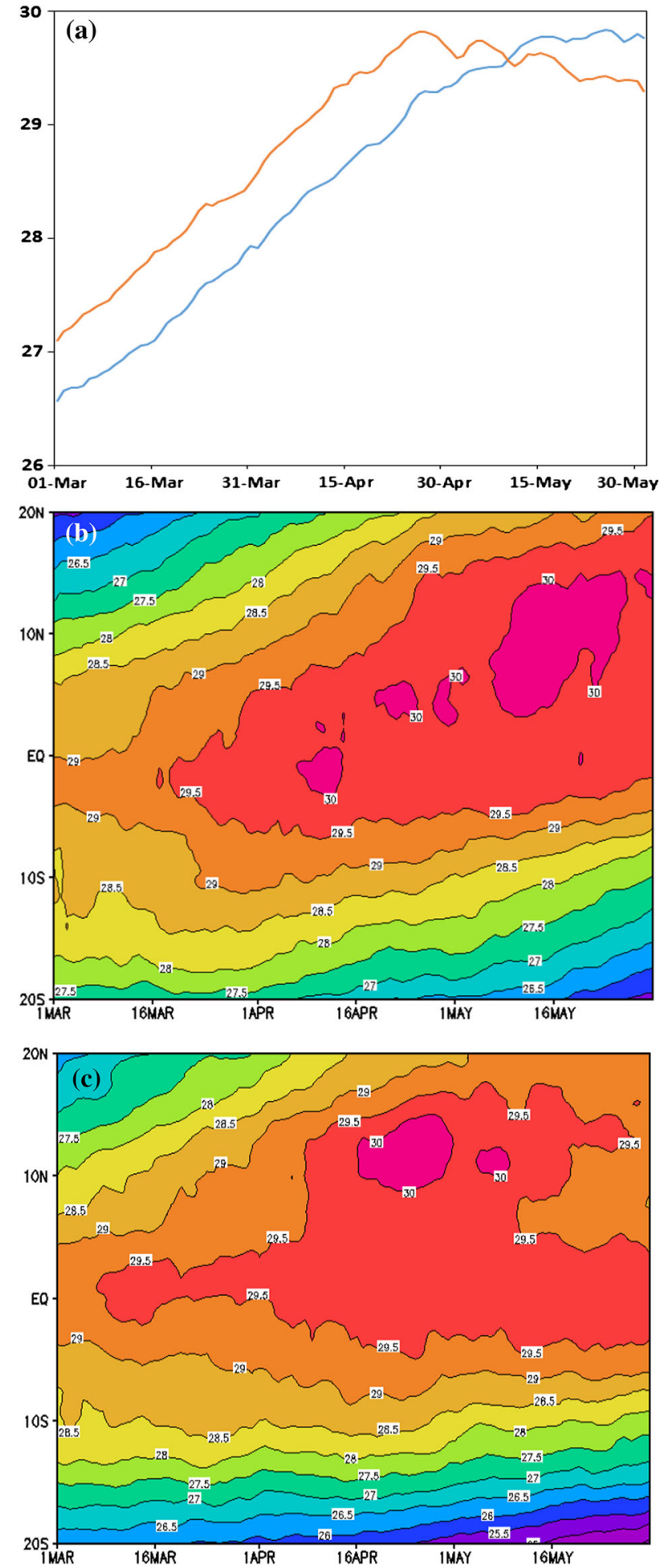

Figure 8. (a) Mean daily $\operatorname{SST}\left({ }^{\circ} \mathrm{C}\right)$ of 1991 to 2010 for 01 March to 31 May of the area $60^{\circ}-70^{\circ} \mathrm{E}, 10^{\circ}-20^{\circ} \mathrm{N}$ (blue curve) and $85^{\circ}-95^{\circ} \mathrm{E}, 10^{\circ}-20^{\circ} \mathrm{N}$ (red curve). (b) Hovmöller of mean daily $\mathrm{SST}\left({ }^{\circ} \mathrm{C}\right)$ of $1991-2010$ between longitudes $60^{\circ} \mathrm{E}$ and $70^{\circ} \mathrm{E}$ for the period 01 March to 31 May and latitudes $20^{\circ} \mathrm{S}$ to $20^{\circ} \mathrm{N}$. (c) Hovmöller of mean daily SST $\left({ }^{\circ} \mathrm{C}\right.$ ) of $1991-2010$ between longitudes $85^{\circ} \mathrm{E}$ and $95^{\circ} \mathrm{E}$ for the period 01 March to 31 May and latitudes $20^{\circ} \mathrm{S}$ to $20^{\circ} \mathrm{N}$.
Table 5. Latitude and longitude of box boundaries.

\begin{tabular}{lcc}
\hline Box & Longitude & Latitude \\
\hline A & $30^{\circ}-120^{\circ} \mathrm{E}$ & $5^{\circ}-20^{\circ} \mathrm{N}$ \\
B & $30^{\circ}-120^{\circ} \mathrm{E}$ & $0^{\circ}-20^{\circ} \mathrm{S}$ \\
C & $30^{\circ}-270^{\circ} \mathrm{E}$ & $5^{\circ}-20^{\circ} \mathrm{N}$ \\
D & $30^{\circ}-270^{\circ} \mathrm{E}$ & $0^{\circ}-20^{\circ} \mathrm{S}$ \\
E & $120^{\circ}-180^{\circ} \mathrm{E}$ & $0^{\circ}-15^{\circ} \mathrm{S}$ \\
\hline
\end{tabular}

moisture in the atmosphere over north Indian Ocean and the adjoining Pacific Ocean making conditions favourable for MOK. We studied the LCC between the 11-year moving averages of the SST gradient between the boxes E (south-west Pacific) and A (north Indian Ocean) of DMOK. The LCC for the months January-February is very low of 0.02 , but that for March-April is high at 0.63 and statistically significant at $99 \%$ level.

\section{ITCZ transitions across the equator and DMOK}

Joseph et al. (1994) had hypothesised that the time of transition of the ITCZ from south to north across the equator is related to DMOK, delayed crossing the equator of the ITCZ associated with delay in DMOK. The ITCZ in monthly climatology has large north-south movement over the Indian Ocean (the longitude zone $30^{\circ}-120^{\circ} \mathrm{E}$ ) studied in this paper due to the monsoonal character of the area. In a large part of the longitude zone $120^{\circ}-270^{\circ} \mathrm{E}$, the ITCZ lies only in the northern hemisphere both in January and July at low latitudes with only a few degrees latitude difference. We have made composite Hovmöller diagrams of the daily OLR averaged between longitudes $30^{\circ}$ and $120^{\circ} \mathrm{E}$ (figure 9) and $120^{\circ}$ and $270^{\circ} \mathrm{E}$ (figure 10) of the period 01 April30 June of years of delayed and early monsoons. For the longitude belt $30^{\circ}-120^{\circ} \mathrm{E}$ (Indian Ocean), the minimum OLR zone has large south to north movement in association with MOK and smaller south to north motion in association with PMRP both for delayed and early MOK. These features have considerable time difference, the crossing of the equator occurring much later in delayed monsoons as compared to early monsoons. For the longitude zone $120^{\circ}-270^{\circ} \mathrm{E}$ (Pacific Ocean), there is no equator crossing of the low OLR zone but only insitu deepening of convection in the ITCZ occurring earlier or later. 
Table 6. LCC between the 11-year moving average of MOK and 11-year moving average of SST gradient for the seasons January-February and March-April.

\begin{tabular}{|c|c|c|c|c|c|c|}
\hline \multirow[t]{3}{*}{ Series } & \multicolumn{6}{|c|}{ Correlations } \\
\hline & \multicolumn{2}{|c|}{ B-A } & \multicolumn{2}{|c|}{$\mathrm{D}-\mathrm{C}$} & \multicolumn{2}{|c|}{ E-A } \\
\hline & JF & MA & JF & MA & JF & MA \\
\hline NK: 1870 to 1980 & 0.04 & 0.52 & 0.51 & 0.53 & -0.09 & 0.67 \\
\hline $\operatorname{IMD}(\mathrm{S}): 1901$ to 2005 & 0.14 & 0.52 & 0.50 & 0.59 & -0.07 & 0.63 \\
\hline $\begin{array}{l}\operatorname{IMD}(\mathrm{S}): 1901 \text { to } 1970+\operatorname{IMD}(\mathrm{O}): 1971 \text { to } \\
2014\end{array}$ & 0.08 & 0.50 & 0.57 & 0.67 & -0.11 & 0.56 \\
\hline $\begin{array}{l}\text { NK+1: } 1870 \text { to } 1900+\operatorname{IMD}(\mathrm{S}): 1901 \text { to } \\
1970+\operatorname{IMD}(\mathrm{O}): 1971 \text { to } 2014\end{array}$ & 0.23 & 0.58 & 0.63 & 0.67 & 0.02 & 0.63 \\
\hline
\end{tabular}

The value which is $99.9 \%$ significant is shown in bold and $95 \%$ significant is shown in italics.
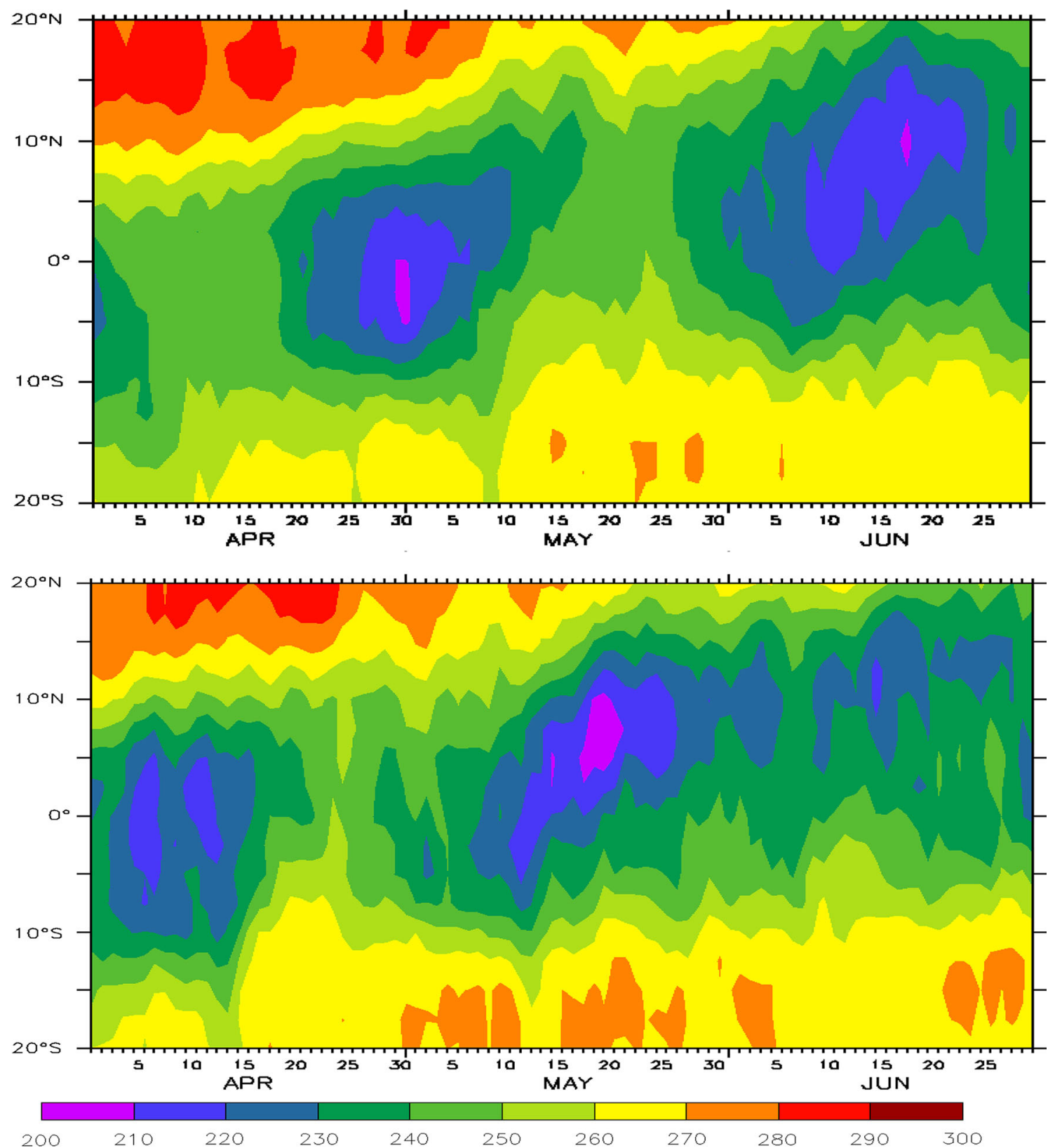

Figure 9. Hovmöller diagrams of the daily OLR $\left(\mathrm{Wm}^{-2}\right)$ averaged between longitudes $30^{\circ}$ and $120^{\circ} \mathrm{E}(\mathrm{Indian}$ Ocean) with delayed (above) and early (below) MOK. 

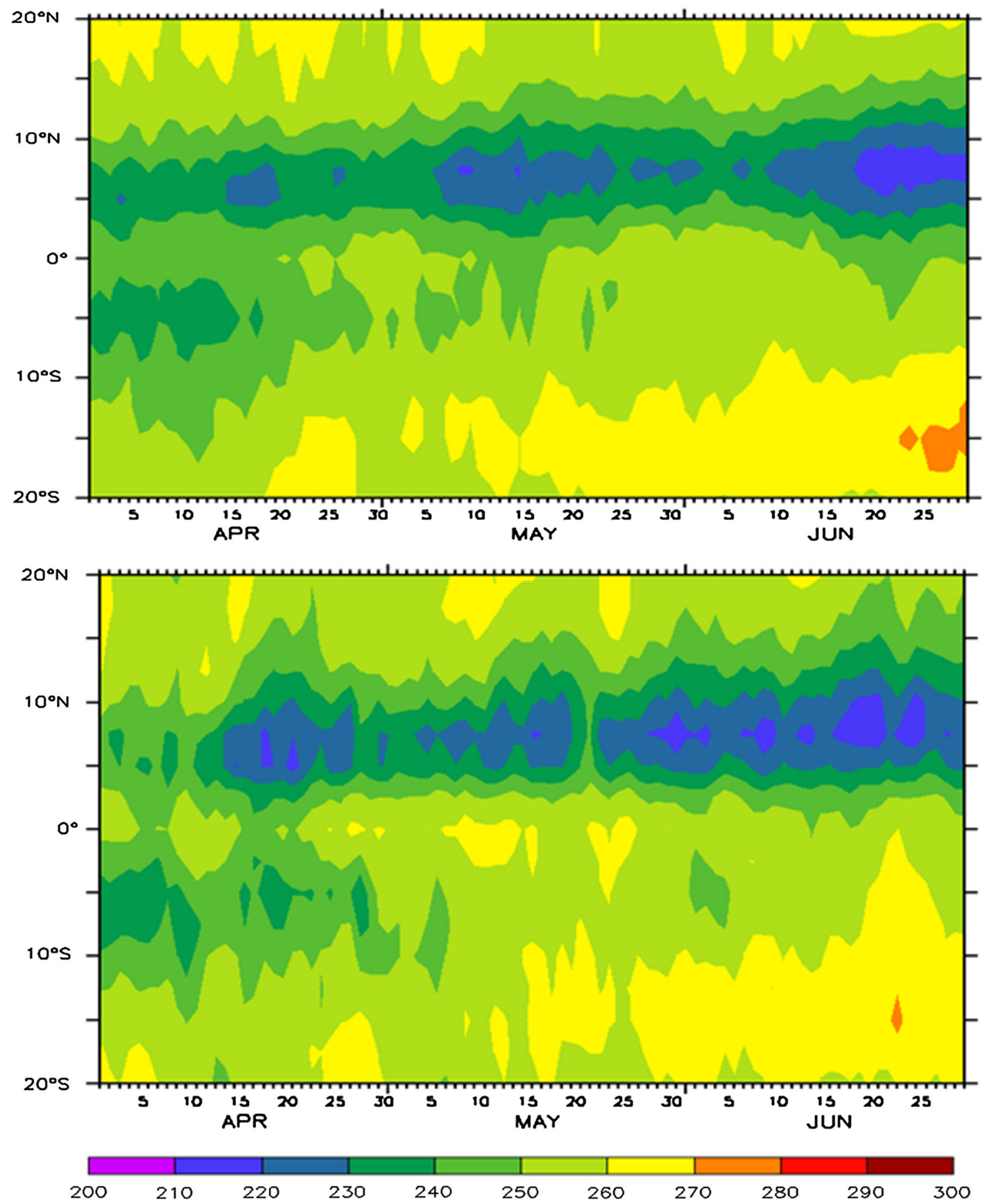

Figure 10. Hovmöller diagrams of the daily $\mathrm{OLR}\left(\mathrm{Wm}^{-2}\right)$ averaged between longitudes $120^{\circ}$ and $270^{\circ} \mathrm{E}(\mathrm{Pacific}$ Ocean) with delayed (above) and early (below) MOK.

\section{MOK, PMRP and convection in the Indo-Pacific ocean basin}

In section 4, pentad averages of OLR over a period of 50 days prior to MOK were studied for both delayed and early MOK cases. It was shown that during the pentads-5, -4 and -3 (in between MOK and PMRP) Indian Ocean has very little convection (high OLR). It is during this period that convection shifts to the west Pacific Ocean (Joseph 1990a, b) and India comes under the downward limb of the Walker circulation. Flatau et al. (2001) have shown that this is the period when India gets increased occurrence of high summer temperature and high frequency of heat waves. Figure 11 gives the area averaged daily OLR 


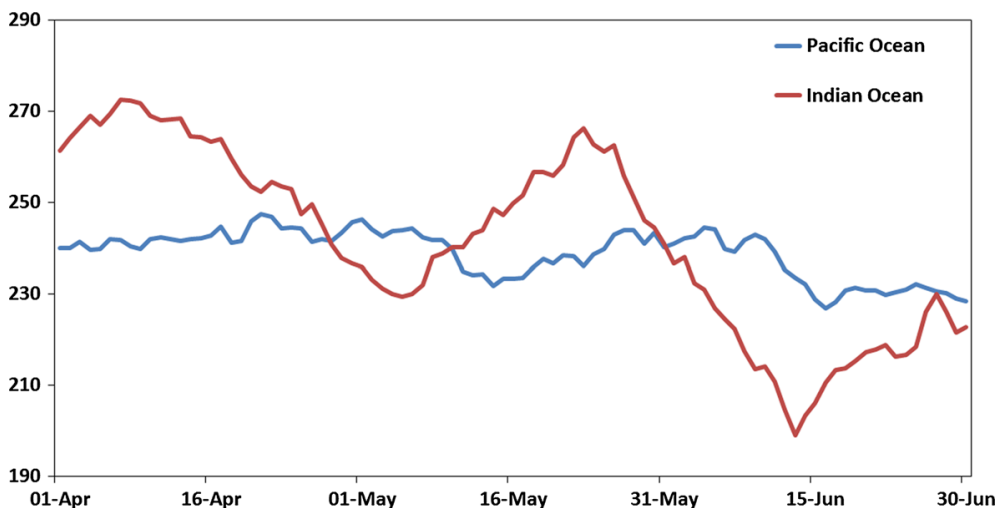

Figure 11. Area averaged daily $\operatorname{OLR}\left(\mathrm{Wm}^{-2}\right)$ of Indian Ocean (blue curve, averaged over $\left.5^{\circ} \mathrm{S}-20^{\circ} \mathrm{N}, 60^{\circ}-90^{\circ} \mathrm{E}\right)$ and west Pacific Ocean (red curve, averaged over $5^{\circ}-20^{\circ} \mathrm{N}, 120^{\circ}-180^{\circ} \mathrm{E}$ ) for composites of delayed monsoon years for the period 01 April to 30 June.

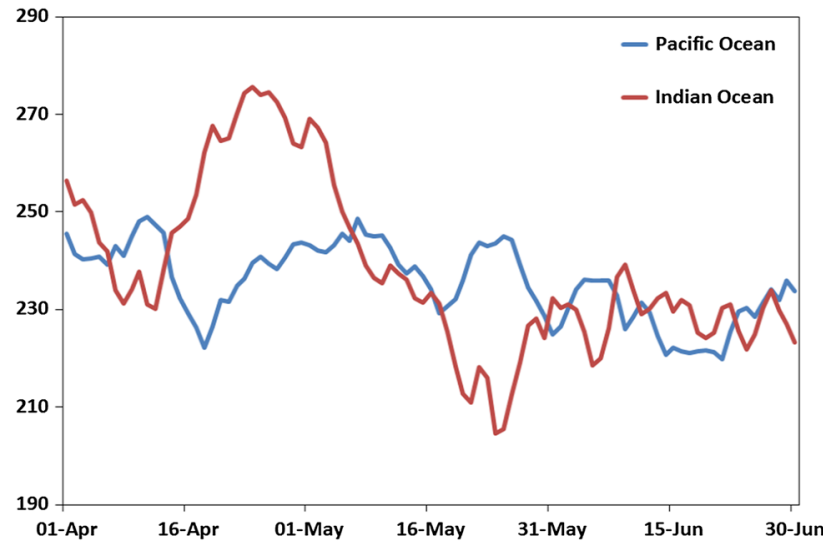

Figure 12. Area averaged daily $\operatorname{OLR}\left(\mathrm{Wm}^{-2}\right)$ of Indian Ocean (blue curve, averaged over $5^{\circ} \mathrm{S}-20^{\circ} \mathrm{N}, 60^{\circ}-90^{\circ} \mathrm{E}$ ) and west Pacific Ocean (red curve, averaged over $5^{\circ}-20^{\circ} \mathrm{N}$, $120^{\circ}-180^{\circ} \mathrm{E}$ ) for composites of early monsoon years for the period 01 April to 30 June.

for delayed MOK years and figure 12 gives the same for early MOK years for the period from 01 April to 30 June. PMRP and MOK are seen in the composites for the Indian Ocean (red curve). It also shows the high OLR period in between. The OLR for these boxes in Indian and Pacific oceans have a high linear correlation at a lag of about 10 days as may be seen from figure 13 . Figure 1 of Joseph et al. (2006) is relevant to this discussion.

\section{Summary}

Spatially large SST anomalies mainly in the Pacific and Indian oceans similar to those associated with El Nino (La Nina) are found to be associated with the delayed (early) occurrence of MOK in individual years. There is a statistically significant variation in the date of MOK on the decadal scale
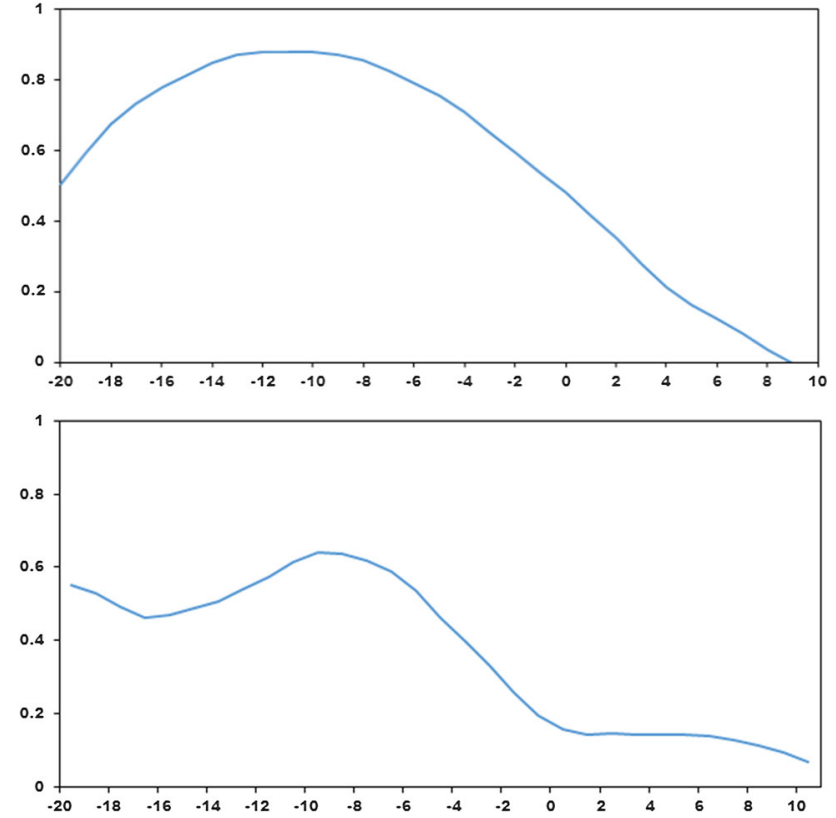

Figure 13. Lag correlation of area averaged daily OLR $\left(\mathrm{Wm}^{-2}\right.$ ) of Indian Ocean (above) (averaged over $5^{\circ} \mathrm{S}-20^{\circ} \mathrm{N}$, $\left.60^{\circ}-90^{\circ} \mathrm{E}\right)$ and west Pacific Ocean (below) $\left(5^{\circ}-20^{\circ} \mathrm{N}\right.$, $120^{\circ}-180^{\circ} \mathrm{E}$ ) for composites of delayed and early monsoon years for the period 01 April to 30 June.

during the last 150 years. In the two decades 1900s and 1910s, MOK was in many years one or two weeks late and in the 1950s and 1960s one or two weeks early. The sea surface temperature (SST) gradient across the equator over the global oceans (Indian and Pacific) is found to have a high and statistically significant linear correlation coefficient with the date of MOK on the decadal scale which has persistence during the months prior to MOK (from January). Increased convection and rainfall occurs over the Indian Ocean around MOK and about 40 days earlier around PMRP or bogus monsoon onset and in between, for about three pentads 
there is a period of suppressed convection and rainfall over the Indian Ocean when increased convection occurs over the west Pacific Ocean. Using the objective DMOK data (free from bogus monsoon onset dates) we have shown that there is systematic change in the convection and rainfall over tropical Indian Ocean with respect to the date of DMOK during the prior 40-day period for composites of years of delayed, early and normal monsoon onset dates. We have also shown that DMOK is closely related to the date when the ITCZ crosses the equator to the northern hemisphere in the Indian Ocean. In years when there is warm SST anomaly south of the equator over the Indo-Pacific Ocean basin (generally associated with El Nino) persisting from January to April, the time of equator crossing of the ITCZ is delayed, leading to a delayed monsoon onset over Kerala.

By combining the available data on the date of monsoon onset over Kerala we have derived a long time series for DMOK spanning the period 1870 2014. Although for the period prior to 1971 this data has not been cleaned from bogus monsoon onsets that occur once in several years, we hope that this dataset will be useful for climate change studies till an objective method is derived for DMOK for the period prior to 1971. The DMOK series derived by Ordoñez et al. (2016) cannot be used to extend the DMOK series back to 1870s (see table 2).

\section{Acknowledgement}

First author gratefully acknowledges receipt of a Junior Research Fellowship from the Council of Scientific and Industrial Research-University Grants Commission (CSIR-UGC), Government of India. This is NIO contribution 6003.

\section{References}

Ananthakrishnan R and Soman M K 1988 The onset of the southwest monsoon over Kerala 1901-1980; J. Climatol. $8283-296$.

Ananthakrishnan R and Soman M K 1989 Onset dates of the south-west monsoon over Kerala for the period 18701900; Int. J. Climatol. 9 321-322.

Ananthakrishnan R, Acharya U R and Ramakrishnan A R 1967 On the criteria for declaring the onset of the southwest monsoon over Kerala; Forecasting Manual. FMU Report No. IV 18.1: 52 India Meteorological Department, Pune, India.
Ananthakrishnan R, Pathan J M and Aralikatti S S 1983 The onset phase of the southwest monsoon; Curr. Sci. 52 $155-164$.

Fasullo J and Webster P J 2003 A hydrological definition of Indian monsoon onset and withdrawal; J. Clim. 16 3200-3211.

Flatau M, Flatau P and Rudnick D 2001 The dynamics of double monsoon onsets; J. Clim. 14 4130-4146.

Joseph P V 1990a Monsoon variability in relation to equatorial trough activity over India and West Pacific Oceans; Mausam 41 291-296.

Joseph P V 1990b Warm pool over the Indian Ocean and monsoon onset; Trop. Ocean-Atmos. Newslett. 53 1-5.

Joseph P V 2012 Onset, advance and withdrawal of monsoon; Monsoon Monograph (eds) Tyagi et al., India Meteorological Department, New Delhi 1 284-329.

Joseph P V 2014 Role of ocean in the variability of Indian summer monsoon rainfall; Surv. Geophys. 35 723-738.

Joseph P V and Pillai P V 1988 40-day mode of equatorial trough for long range forecasting of Indian summer monsoon onset; Curr. Sci. 57 951-954.

Joseph P V, Eischeid J K and Pyle R J 1994 Interannual variability of the onset of the Indian summer monsoon and its association with atmospheric features, El Niño and sea surface temperatures anomalies; J. Clim. 7 81-105.

Joseph P V, Sooraj K P and Rajan C K 2006 The summer monsoon onset process over south Asia and an objective method for the date of monsoon onset over Kerala; Int. J. Climatol. 26 1871-1893.

Krishnamurti T N 1985 summer monsoon experiment - A review; Mon. Wea. Rev. 113 1590-1626.

Li C and Yanai M 1996 The onset and inter-annual variability of the Asian summer monsoon in relation to land-sea thermal contrast; J. Clim. 9 358-374.

Liebmann B and Smith C A 1996 Description of a complete (interpolated) outgoing longwave radiation dataset; Bull. Am. Meteor. Soc. 77 1275-1277.

Ordoñez P, Gallego D, Ribera P, Peña-Ortiz C and GarcíaHerrera R 2016 Tracking the Indian summer monsoon onset back to the preinstrument period; J. Clim. 298115 8127.

Pai D S and Rajeevan M 2009 Summer monsoon onset over Kerala: New definition and prediction; J. Earth Syst. Sci. 118 123-135.

Pearce R P and Mohanty U C 1984 Onsets of the Asian summer monsoon 1979-1982; J. Atmos. Sci. 41 16201639.

Rayner N A, Parker D E, Horton E B, Folland C K, Alexander L V, Rowell D P, Kent E C and Kaplan A 2003 Global analyses of sea surface temperature, sea ice, and night marine air temperature since the late nineteenth century; J. Geophys. Res. 108 D144407, doi: 10.1029/ 2002JD002670.

Reynolds R W, Smith T M, Liu C, Chelton D B, Casey K S and Schlax M G 2007 Daily high resolution blended analysis for sea surface temperature. J. Clim. 205473 5496.

Sabeerali C T, Rao S A, Ajayamohan R S and Raghu Murtugudde 2012 On the relationship between Indian summer monsoon withdrawal and Indo-Pacific SST anomalies before and after 1976/1977 climate shift; Clim. Dyn. 39(3) 841-859, doi: 10.1007/s00382-011-1269-9. 
Saji N H, Goswami B N, Vinayachandran P N and Yamagata T 1999 A dipole mode in the tropical Indian Ocean; Nature 401 360-363.

Soman M K and Krishna K K 1993 Space-time evolution of meteorological features associated with the onset of the Indian summer monsoon; Mon. Wea. Rev. 121 11771194 .

Corresponding editor: A K SAHAI
Wang B, Ding Q and Joseph P V 2009 Objective definition of the Indian summer monsoon onset; J. Clim. 22(12) 33033306, doi: 10.1175/2008JCL12675.1.

Xavier P K, Marzin C and Goswami B N 2007 An objective definition of the Indian summer monsoon season and a new perspective on the ENSO monsoon relationship; Quart. J. Roy. Meteorol. Soc. 133 749-764. 